\title{
The Transatlantic Rift: Ideological Roots and Implications for Central and Eastern Europe*
}

\begin{abstract}
The recent transatlantic row is not merely about ways of dealing with specific issues of international concern such as the war in Iraq. The rise of anti-American sentiments in Europe seems to imply that there is a deeper rift in the transatlantic alliance. There are several explanations of this phenomenon. They are not mutually exclusive, since they can be subsumed under a more general explanation pointing to two different ideologies, those of individualism and collectivism, prevalent respectively on the western and the eastern side of the Atlantic (or possibly, the Dover strait). The difference is reflected in the policies both at the domestic and at the international level: the American distrust of big government contrasts sharply with the European statism, and the American reluctance to submit to supranational rule, contrasts with Europeans' readiness to embrace post-national governance. The Central and East European countries have sided with America (and NATO) for reasons of security, and they have also sought a closer European integration for the reasons of economic growth. The two objectives might prove to be incompatible, unless Europe moves to the more individualist and dynamic Anglo-Saxon model of economic development as against that of "social market" favored by Germany and France.
\end{abstract}

\section{Introduction}

An observer of the international scene should have found it strange that after the horrible attacks of $9 / 11$ the West has not closed its ranks in the face of the new threat. On the contrary, the two main partners of the Western world, the USA and Western Europe, have become increasingly divided over major issues of international concern and have drifted apart in their domestic and foreign policies. Some fundamental differences have emerged in their views on the desirable international order and on the ways of dealing with the threats facing it. The simplest explanation of the rift is the one appealing to the clash of the ambitions of current political leaders on both sides of the Atlantic. However, its

* Dr. Algirdas Degutis is a Senior Fellow of the Lithuanian Institute of Culture, Philosophy and Art, Address: Saltoniškiu 58, Vilnius, Lithuania; tel. +370 5273 7658; algirdas@ktl.mii.lt

** I am grateful to the colleagues of the COST Action 24 program („Evolving social construction of threats") for inspiring research assistance. I am especially indebted to Pertti Joenniemi for comments on an earlier draft of this paper. 
naïveté is revealed by the strange phenomenon of the upsurge of anti-Americanism in Western Europe after 9/11. This was the way Western European societies and their intellectual leaders responded to the belligerent pronouncements and the military responses by America to the attacks of $9 / 11$. What is behind this European pacifism? We shall consider several hypotheses proposed as explanations of the phenomenon and as answers to this question, and then formulate a more general hypothesis which, as it seems, helps explain all the major controversies between the USA and Western Europe. Finally, we shall consider the implications of the rift for Central and Eastern European countries by concentrating on the tensions that have emerged between these countries' security policies and their hopes of economic growth placed in the Western European "social model".

\section{The Reemergence of European Anti-Americanism}

A remarkable feature of the recent quarrels between the American and European political elites over issues of international concern is that they have been accompanied by the spread of anti-American sentiment in Western Europe. The anti-Americanism of European elites has been a familiar phenomenon since the very foundation of the United States. However, in the past it was never matched by the same sentiment of the European "masses". Ordinary Europeans felt no hostility to America. In fact, many of them preferred the New World, the "land of opportunity", to the Old World - by voting massively, with their feet, for America. Things have changed. Now even the "masses" are solidly behind the European elites in their suspicion of, and hostility to, America.

As Glenn Frankel wrote in the Washington Post: "Anti-Americanism, West European-style, is widespread, rising and migrating from its traditional home among left-wing intellectuals, academics and café society to the political mainstream... Countries such as France, Germany and Britain, which for more than five decades have been the closest allies of the United States, are beginning to drift away, propelled by a popular wave of concern, alarm and resentment. The immediate focus might be U.S. policy toward Iraq, but the larger emerging theme is an abiding sense of fear and loathing of American power, policies and motives." ${ }^{11}$ According to a Pew survey, a year after the war in Iraq, "discontent with America and its policies has intensified rather than diminished. Opinion of the United States in France and Germany is at least as negative now as at the war's conclusion, and British views are decidedly more critical. Doubts about the motives behind the U.S.-led war on terrorism abound and a growing percentage of Europeans want foreign policy and security arrangements independent from the United States." The survey of 2005 showed that percentage of the population

${ }^{1}$ Frankel, Glenn, "Anti-Americanism Moves to W. Europe's Political Mainstream," Washington Post, Tuesday, February 11, 2003; Page A01. 
holding favorable views of the United States has dropped in France from 62 percent in 2000 to 37 percent in March 2004 (43 in 2005) and in Germany from 78 percent to 38 (41 in 2005) percent in the same period. ${ }^{2}$

West Europeans now doubt U.S. good will, mistrust U.S. policies, resist U.S. intrusion in European politics and many consider George Bush a greater threat to world peace than Kim Jong-il. Historian James Ceaser quotes the French analyst Jean-François Revel, according to whom "If you remove anti-Americanism, nothing remains of French political thought today, either on the Left or on the Right" and adds that the same is true of Germany and of almost any other Western European country: "anti-Americanism now reigns as the lingua franca of the intellectual class in Europe." ${ }^{3}$ And the European "masses" lend it solid support.

But what is anti-Americanism? It should certainly be distinguished from mere criticism of the United States. In P. Hollander's definition, "anti-Americanism" denotes a "particular mind-set, an attitude of distaste, aversion, or intense hostility the roots of which may be found in matters unrelated to the actual qualities or attributes of American society or the foreign policies of the United States. In short, anti-Americanism refers to a negative predisposition, a type of bias which is to various degrees unfounded.... [It is] an attitude similar to [such other] hostile predispositions as racism, sexism, or anti-Semitism.." ${ }^{4}$ Does the European anti-American sentiment satisfy this definition? It seems that it does. The sentiment is now so profound and deep-seated that it has little or nothing to do with any actual US policies; rather it reflects a blanket, out of hand rejection of anything the United States does at any place at any time. The dominant perception is that America rides roughshod over international laws and treaties and threatens stability and peace the world over. America is hypocritical in its foreign dealings and it wields its unparalleled military power unilaterally. In short, despite its rhetoric of fighting "rogue states" in the global arena America is itself a rogue state, a bull in the global china shop. America's domestic policies are also seen as fundamentally flawed. The US is perceived as a selfish, individualistic society singularly driven by the profit motive and spreading its greedy corporate reach over the globe. It is uncaring of its own poor and indifferent to the rest of mankind. The "European street" is prone to stereotype Americans as obese, loud-voiced, ill-mannered children roaming the planet, armed with deadly guns.

This is a discourse expressing pervasive animosity and suspicion against the United States, its government and its people, a discourse which sees the US as a global predator whose actions are conditioned by its evil grabbing nature. The discourse is not merely critical, it is one of total damnation. The target of the

${ }^{2}$ The Pew Survey Report of March 16, 2004: “A Year after Iraq War. "The Pew Survey Report; “U.S. Image Up Slightly, But Still Negative”, released: 06.23.05. http://pewglobal.org/reports/display.php?PageID=800, 15092005.

${ }^{3}$ Ceaser, J., "A Genealogy of Anti-Americanism", The Public Interest, Summer 2003.

${ }^{4}$ Hollander, P., Anti-Americanism: Irrational and Rational, Transaction Publishers, 1995, p. lxxviii. 
critique is beyond redemption. In this kind of totalizing critique the target is given no opportunity of mending its ways, no chances of improving its character. America is criticized for being interventionist and for being isolationist, and the same person can make both criticisms in the same breath. There is no action or inaction, no omission or commission on its part that can falsify the bias against it. The criticism is rationally unassailable. It needs no logic, or is led by the logic of conspiracy theories.

The stance is strikingly similar to anti-Semitism. The reasons for attacking America constitute much the same sets of contradictory claims: like Jews, Americans are overzealously religious, but also crassly materialistic; they are stingy, but also spendthrifts; they are uncultivated, but also intent on imposing their own culture on the rest of the world; they are aggressive, but also cowardly; they are stupid, but also exceptionally cunning, etc. It was in this vein that Franz Müntefering, the chairman of Schröder's Social Democratic Party (SPD), compared American financial dealers operating in Germany to "swarms of locusts" ravaging German companies ${ }^{5}$ - the kind of language used by the Nazis to describe Jews. The bias is also conspicuous in many publications and public declarations. A best-selling book "9/11: The Big Lie" by one Thierry Meyssan ${ }^{6}$ claimed that the 9/11 attacks were mostly a fabrication of the American government; in fact, so Meyssan alleges, they were planned by the right-wing cabal in the U.S. government and actually carried out by the American military, to advance their own interests - a palpably crazy idea. The book's popularity highlights the basically irrational, and yet evidently appealing, character of antiAmericanism in Europe. A popular new book in Germany is Eric Frey's Schwarzbuch USA (Black Book USA). It is a 497-page catalogue of American crimes throughout history, beginning with the "annihilation of the Indians."

The oft-repeated complaint is that George W. Bush squandered international sympathy for the United States, prompted by the terrorist blood-bath of 9 / 11. However, in reality he had little to squander. With the Twin Towers still smoldering European intellectuals were already indulging in a virtual feast of Schadenfreude. The famous French philosopher, Jean Baudrillard, notoriously declared: "Basically, they [the terrorists] did it, but we wanted it. ... Terrorism is immoral, and it responds to a globalization that is itself immoral". ${ }^{7}$ Another French celebrity, philosopher Jacques Derrida, went so far as to virtually justify the attacks - by 'deconstructing' the notion of terror. Derrida wonders: "We are perhaps wrong to assume so quickly that all terrorism is voluntary, conscious, organized, deliberate, intentionally calculated: there are historical and political "situations" where terror operates ... as if by itself, as the simple result of some apparatus, because of the relations of force in place, without anyone ... being really conscious of it or feeling itself responsible for it". And he goes on: "Can't one terrorize without killing?" "Can't 'letting die', 'not wanting to know that one is letting others die'-hundreds of millions of human beings, from hunger,

${ }^{5}$ In an interview to Bild am Sonntag, April 17, 2005.

${ }^{6} 11$ septembre 2001: L'Effroyable Imposture, Chatou: Carnot, 2002.

${ }^{7}$ Baudrillard, J., The Spirit of Terrorism (Verso), 2002, p. 134. 
AIDS, lack of medical treatment, and so on - also be a part of a 'more or less' conscious and deliberate terrorist strategy?" ${ }^{\prime 8}$ The implied suggestion is that the terrorists acted in legitimate self-defense - against the terror of America's omission.

Another luminary, German philosopher Jürgen Habermas, just as readily identified the 'root causes' of the terrorist attacks: "Without the political taming of an unbounded capitalism, the devastating stratification of world society will remain intractable. The disparities in the dynamic of world economic development would have to at least be balanced out regarding their most destructive consequences - the deprivation and misery of complete regions and continents comes to mind. ${ }^{\prime \prime}$ Since America is quintessentially associated with the evils of 'unbounded capitalism', the attacks are therefore at least understandable, if not justifiable.

This perception of the 'root causes' of terror has repercussions for Europe's view on its relations with America. While most Americans regard 9/11 as an attack on Western civilization by an implacable enemy, Europeans tend to regard it as a response to specifically American policies, representing a risk from which they are largely immune. They feel immune because, though formally still America's allies, they see themselves different from Americans. And this perception of themselves as 'un-American' shapes their conception of the Islamist threat. Since America is so expansive, overpowering and arrogant, and since it is basically an exploitative capitalist society, attacks on it by those who feel threatened or exploited by it are only to be expected. The radical Left go even farther and proclaim America itself as the 'root cause' of terrorism. With these perceptions, the policy options for the Europeans are either shaming America into mending its ways or disengaging from America in order to avoid similar attacks on themselves. Since there is little or no hope of achieving the former goal, the only option of averting the Islamist threat seems that of disengagement from America. (Spain's reaction to the terrorist attack might be a case in point.) Americans might condemn this policy as surrender, as an appeasement of the implacable enemy, as another Munich. However, for Europeans, who see America itself a 'rogue state', this might seem the right policy. Actually, there is no common perception of the roots of Islamist threat that could help close the divide between Europe and America. Since many Europeans tend to perceive the threat as a derivative one from that posed by America itself, dissociating from America is a reasonable option for them.

The European formula ready at hand for the explanation of all the world's discontents is now remarkably simple: "blame America first". Anything going wrong in the world is an indictment on America; it can be faulted on America's omission or on America's commission. Since America is so powerful and yet so

\footnotetext{
${ }^{8}$ In Borradori, G., Philosophy in a Time of Terror: Dialogues with Jürgen Habermas and Jacques Derrida, University of Chicago Press, 2003, p. 107-108.

${ }^{9}$ Op. cit., p. 36.
} 
deeply vicious, there is apparently no action undertaken by her abroad that would not provoke protests by those watchful of her mischievous ways, and there is apparently no target, no country, no regime so wrong that an American effort to destroy or to change it would not lead to righteous recriminations against America's imperial reach, unilateralism and "Manichean" arrogance. This is now the dominant stance of European intellectuals and street protesters, as well as of America's far left 'Bush-bashers' such as Noam Chomsky and Michael Moore.

There is obviously a pragmatic inconsistency here: blaming America for her evil doings presupposes that America, unlike the former Soviet Union or North Korea, is responsive to blame and thus not as evil as her detractors presume. One should note that mass demonstrations in Western Europe against America's war in Iraq were never matched by demonstrations against the tyranny of Saddam. And the media outcry against prisoner abuse at AbuGraib or Gitmo has never been matched by an outcry against the videotaped beheadings of civilians in Iraq. For East and Central Europeans this is a reminder of another amazing fact. Mass demonstrations in Western Europe against the deployment of US intermediate-range missiles in Europe in 1980s were never matched by demonstrations against the tyranny of the Soviet regime. Again, for someone from the East and Central Europe it is amazing, that what prompted Jürgen Habermas and Jacques Derrida to proclaim, in the famous manifesto published in major Western European newspapers, the birth of the 'European public forum' were mass demonstrations against America's war in Iraq on February 15, 2003. ${ }^{10}$ In their view, the event was "the most significant since the end of the Second World War". The implication is that the fall of the Berlin Wall, the collapse of the Soviet Union and the end of its rule over the eastern part of the European continent was much less significant. Apparently, in contrast to America, the Soviet Union was not evil enough to mobilize Europe and to give birth to the 'European public forum'. Nor, as it seems, is the Islamist terrorism evil enough for Europe to get united with America against it.

Current European anti-Americanism is only tangentially related to the post-9/11 foreign policy of the Bush administration. America was notoriously castigated as an arrogant hyperpuissance by Hubert Védrine, French minister of foreign affairs, during the Clinton administration. The antiglobalization movement led by the Attac organization in France was vehemently anti-American since its inception in 1998 and it had such luminaries as the philosopher and sociologist Pierre Bourdieu, a harsh critic of 'neoliberalism', among its most active members. It was in 1999 that the French anti-globalization activist José Bové destroyed a McDonalds' restaurant in France in an act of symbolic vandalism. Thus, for a long time already European anti-Americanism extends beyond

10 "Nach dem Krieg: Die Wiedergeburt Europas", Frankfurter Allgemeine Zeitung, 2003/05/31 "Europe: plaidoyer pour une politique extérieure commune", Libération, 2003/05/31 - 2003/ 06/01). 
any criticism, right or wrong, of American foreign policies. As Revel puts it in his Anti-Americanism, it is a kind of an 'irrational surplus', an 'obsession'. It will hardly disappear when the current occupants of the White House retire to their ranches or if the current leaders of the 'core Europe' leave their posts. The sources of the antagonism seem to lie at a deeper level than that of disagreements on current international policies; they have to do with the intellectual climate now reigning in Western Europe.

The recent wave of European anti-American obsession has its inevitable costs. In fact, it is highly counterproductive. It drowns even reasonable criticism of American policies in the avalanche of prejudiced invectives and it makes Americans more likely to shrug off all European criticism as totally flawed and irrelevant, and to consider Europe as "old and in the way" (Karl Zinsmeister) or to revile the French as "cheese-eating surrender monkeys." Paradoxically, vehement anti-Americanism is quite likely to make Europe's influence on America still less significant.

\section{Explanations: Imbalance of Power and Dependency}

How can one explain this rift in transatlantic relations? Is it just another family quarrel in the community of the West? Or is it symptomatic of deeper divisions that have been developing for some time and were only revealed by the crisis over Iraq? Robert Kagan ${ }^{11}$ put forward the now famous explanation which is readily applicable to current European anti-Americanism and its American backlash, Europhobia. "It is time to stop pretending," he says, "that Europeans and Americans share a common view of the world, or even that they occupy the same world". He goes on drawing a "dual caricature" of Europeans - as Venusians, believing in a Kantian "self-contained world of laws and rules and transnational negotiation and co-operation" and Americans - as Martians, convinced that military muscle and power is still much needed in the Hobbesian jungle beyond Europe's cozy bubble of the postmodern paradise.

In Kagan's view, “The reasons for the transatlantic divide are deep, long in development, and likely to endure." First, there is the factor of European military weakness and America's unprecedented military power - the factor that was itself partly created by America providing a safety net for Europe during the Cold War era. Weakness generates a certain psychology, a certain mental attitude: when you are weak you tend to lay low, to seek negotiations and peaceful settlements, to appeal to norms and laws binding to all. You are averse at showing muscle as indicating the possible use of force even as the last resort. In a vivid simile, Kagan writes that a man walking through a forest armed with a knife will have a different response to a prowling bear than a man armed with

${ }^{11}$ Of Paradise and Power, Alfred A. Knopf, 2003. 
a rifle. Second, there is a factor of Europe's history - a factor that explains Europeans' drift to a different world-view. Shocked and shamed by their own bloody past, they place the highest premium on peace as a value in itself. They aspire to a Kantian, end-of-history world of perpetual peace. And they want others to imitate their model of integration. Thus being both weak and peace-loving, they would rather not hear the growls from the jungle outside their paradise and would be upset by anyone showing off muscle.

According to Kagan, the European vision is only partially right. Europeans have indeed created a Kantian world for themselves, now within the European Union, where the former anarchy of sovereign states has given way to a transnational, or even supranational organization, a largely peaceful world that to an increasing degree can be governed by law, norms and international agreements. However, what they don't understand is that the peace and safety of their Euro-bubble is ultimately guaranteed by American power. Their Kantian world was made possible and was in fact created under a shelter screening them off from the wider world - only because America stood on guard on the walls of the West, between it and the rest of the anarchic Hobbesean world.

One can decipher in the Venus/Mars metaphor an allusion to Europe's 'femininity' in revolt against America's 'masculinity' - the revolt of someone weak, yet presumably on higher moral grounds, intent to subdue the stronger and to direct the ways his power is exercised. However, the option of assuming all the risks for taking action in the world while being guided by someone bearing little or no costs of the action is something America cannot afford. Europe's 'feminist' demands, though possibly valid in her own small world, cannot be accepted by America acting in the wide world. Europeans live under illusion. They think that they are autonomous and self-sufficient; unaware that without the Americans standing by they would be dragged back into history.

There is a certain tension in Kagan's explanation: are Europeans pacifists because they do not have enough guns, or do they not have enough guns because they are pacifists? Kagan seems to favor the former view, though he also allows for an influence the other way round. Further, some of these differences he attributes to the fact that, since the end of the Cold war, Europeans have sought to define "Europe" as something apart from America, rather than seeking a common definition of "the West" in the post Cold War era. His remedy, rather tentative and not very optimistic, is twofold. First, Europe should stop being a "military pygmy" and spend more on defense and the military. Second, Europe should recognize that, beyond the postmodern world of the EU, there is a modern and a pre-modern world outside. Europeans may be Kantian in their village, but they must be Hobbesian in the jungle around and welcome the United States assuming the role of global Leviathan. One may add: they should, but would they?

There are some similar, though more psychologically based, explanations of the rift. American military historian Victor Hanson and French political philosopher Pascal Bruckner descry the "dependency syndrome" and the "debtor's complex" behind the European animosity. Being "free-riders" on Ameri- 
ca's security welfare the Europeans have developed dependents' resentment of the benefactor. Precisely because America protects Europe, Europe will need ever more protection, and will grow ever weaker. And because it will need the United States to defend it, it will ever more resent the United States. America's six-decade security guarantee to Europe has been a strategic error. The basic flaw in the Atlantic alliance is that for almost all its participants the free world is a "free lunch": a defense pact of wealthy nations in which only one party pays the bills. Like any other form of welfare, defense welfare is a hard habit to break and profoundly damaging to the recipient. As Bruckner puts it: "the more we curse the United States, the more we depend on it. We are like a child who rebels against his parents so that he will never leave them." ${ }^{12}$ In fact, this is not a new diagnosis. As far back as in 1982 British historian Michael Howard offered a similar generalization: "The peoples of Western Europe effectively abandoned responsibility for their own defense. Their own armed forces, forces which have always had the social role of embodying national self-consciousness and will to independent existence, became almost peripheral, part of a mechanism of nuclear deterrence the ultimate control of which lay elsewhere."13

On this view, the peculiarly obnoxious character of postmodern Europe is a consequence of Washington's willingness to absolve it of responsibility for its own security. In fact, America's military presence in places like Germany does real damage in enabling an opportunistic pacifism and anti-Americanism fueled by dependency and ignited by resentment. America's saying good-bye to Europe would be the best solution of European anti-Americanism and it could open the prospects for more mature relations.

\section{Deeper Reasons: the Ideological Divide}

Still, can we ultimately explain the European revolt against America in terms of the power imbalance and the psychology it generates (resentment of the benefactor, diminished perception of threats, an appeasement mentality)? What if, as historian Tony Judt contends, "Europeans 'underspend' on defense not just because the American guarantee allowed them to enter a garden of perpetual peace, but because in the third quarter of this century they chose to devote a lot of money to expensive (and very popular) public services"? The expanding welfare state, the collective provision of ever more goods, has been squeezing out private endeavor, and "just as the public sector has displaced individual initiative in many parts of national life, so the habit of collaboration shapes European approaches to international affairs." ${ }^{14}$

\footnotetext{
${ }^{12}$ Hanson, V., "Goodbye to Europe?" Commentary, October 2002; Bruckner, P., "Europe: Remorse and Exhaustion", Dissent, Spring 2003.

${ }^{13}$ Howard, Michael, "Reassurance and Deterrence: Western Defense in the 1980s," Foreign Affairs, vol. 61, no. 2 (Winter 1982/1983), pp. 312-313.

${ }^{14}$ Judt, Tony, "Its Own Worst Enemy", The New York Review of Books, August 15, 2002.
} 
In deploring America's unilateralism Europeans are giving expression to their own particular vision of both domestic and international policy - a vision which can be characterized as collectivist in distinction to the much more individualist one espoused by the Americans. The difference manifests itself in various ways. One is the relative value put on individual 'self-reliance', which is very high with the Americans. Europeans, by contrast, tend to exalt 'solidarity'. The percentage of Americans who believe that success is determined by forces outside their control has fallen from 41 percent in 1988 to 32 percent today; by contrast, the percentage of Germans who believe it has risen from 59 percent in 1991 to 68 percent today. ${ }^{15}$ Another difference is Americans' endorsement of capitalism and their celebration of the creative genius of the business people, which is only comparable to the French celebration of the creative genius of artists and intellectuals. Next, there is the widespread anti-statism of the Americans, boosted by the conservative revolution of Ronald Reagan. Government is considered by most Americans as part of the problem, not part of the solution, as is the case with most Europeans. Related to this is American religiosity, a character trait that "has encouraged Americans to see problems in terms of individual virtues and vices. It has also encouraged Americans to try to solve society's ills through voluntary activity rather than state action."16 Europeans, by contrast, are much more secular. Indeed, radical secularism has become a kind of religion for many Europeans. Finally, Americans are deeply patriotic and nationalist in a way that is embarrassing to the Europeans, who, because of their bloody history of nationalist wars, tend to associate nationalism with xenophobia and chauvinism and are now engaged in a grand project of dissolving national identities in the European superstate.

These are substantial ideological differences and it seems that they are becoming even more prominent. The old cliché of 'common Western values' might be false, if the basic values - freedom, human rights, etc. - are interpreted differently on the two sides of the Atlantic. Indeed, as Tony Judt observes, "What Europeans find perturbing about America, then, is precisely what most Americans believe to be their nation's strongest suit: its unique mix of moralistic religiosity, minimal provision for public welfare and maximal market freedom - the "American way of life" - coupled with a missionary foreign policy ostensibly directed at exporting that same cluster of values and practices."17 It was precisely the American way of life that was condescendingly dubbed by Gerhard Schröder as "amerikanische Verhältnisse", not to be imitated by Europe.

To be sure, the day to day politics in America and Europe are not thus starkly different-Americans have imbibed large doses of statism since the 1960s, while Europeans formally embrace liberal democracy. Yet their deeper attitudes are different, even opposite. "Americans, writes Pascal Bruckner, understand freedom as a "dream". They chose liberal democracy as the best of all systems, while many Europeans embraced liberalism because more exciting alternatives

\footnotetext{
${ }^{15}$ Micklewait, John and Wooldridge, Adrian, The Right Nation: Conservative Power in America, The Penguin Press, 2004, p. 312.

${ }^{16}$ Micklewait and Wooldridge, Op. cit., p. 326.

${ }^{17} \mathrm{Judt}, \mathrm{T} .$, "It's the anti-American Way", Financial Review, April 17, 2003.
} 
had disappointed them."18 The center of gravity of American public opinion is much further to the right (more classically liberal) than in any other developed nation. Europe has never had (with the exception of Thatcher's England) any movement analogous to the conservative movement in America that has been on the rise for the last 30 years. And America has never had a major party or a movement resembling European social democracy. As the title of the book by Micklethwait and Woolridge has it, America is the "Right Nation".

Since America is conceived by Europeans as a brazenly capitalist country and since they reject capitalism (except as a last resort the well-regulated, tame sort) insisting on the widening and deepening of the sway of "social justice", the two visions necessarily clash. It is no accident that anti-Americanism in Europe goes hand in hand with the anti-globalization movement, often in tandem with anti-Semitism - since all these movements and sentiments are virulently anticapitalist and vehemently opposed to the 'neo-liberalism' promoted by America. As Jean-François Revel points out, "The principal function of anti-Americanism has always been, and still is, to discredit liberalism by discrediting its supreme incarnation." ... "Behind the fight against globalization lies an older and more fundamental struggle against liberalism, whose chief representative and most powerful vehicle is the United States". ${ }^{19}$ (To prevent misunderstanding, 'liberalism' is used by Revel in the European sense; in America the meaning of the term is rendered roughly by 'conservatism').

It is not the case that the French and the Germans, or even the British, were passionately pro-American during the Cold War. But as long as the Soviet empire was menacing Western Europe with missiles and troops at its borders, there was a very practical reason for the unity of the West. However, with the menace gone the incentives for transatlantic harmony have grown steadily weaker, while the ideological differences have grown starker. There is also a connection between the fall of the Berlin Wall and the rise of 'anti'- movements on the left of the political spectrum. After the demise of 'real socialism' and with Marxism falling in disrepute the left has lost the positive grounds for its unity. Though it can appeal to such vague notions as "social justice" or "progressive values", the real glue of the unity of the left today (both in Europe and America) is its opposition to, and resentment of, the United States, the embodiment of the system they consider evil, even if indispensable..$^{20}$ The US model of capitalism is culturally and philosophically alien to the European political mainstream. The American or, more broadly, the "Anglo-Saxon" model is conceived as a danger to the European view of society. This is why the defense of the "European social model", a code word for a highly regulated, corporatist economy, is now the common endeavor of the labor unions on one side and the anti-globalization and anti-American opinion-makers on the other..$^{21}$

\footnotetext{
${ }_{18}$ Bruckner, P., Op. cit.

${ }^{19}$ Revel, Jean-François, Anti-Americanism, Encounter Books, 2003, p. 12, 31.

${ }^{20}$ Markovits, Andrei S., "The European and American Left since 1945", Dissent, Winter 2005, p. $5-14$.

${ }^{21}$ Two recent books defending the European and the "Anglo-Saxon" model are, respectively, Jeremy Rifkin, The European Dream: How Europe's Vision of the Future is Quietly Eclipsing the American Dream, Tarcher/Penguin, 2004; Olaf Gersemann, Cowboy Capitalism: European Myths, American Reality, CATO Institute, 2004.
} 
These different visions of a good society have repercussions at the level of international relations. On the one hand, American domestic individualism naturally translates into international unilateralism. Just as Americans typically believe that in domestic public life citizens are best left to their own devices, with limited government intervention, so they project this view onto international affairs as well. The emphasis upon "exit strategies," upon being in the world community but not quite of it, always at liberty to retire from the global scene, has its domestic analogue in the individualism of American life. On the other hand, Europe's international 'multilateralism' is a translation at the international level of domestic collectivism, of the "voice strategies" (to use Hirschman's terms). The underlying idea is that of collective responsibility, joint action, submission to a higher authority of the state (domestically) or the 'international community' (globally).

The transatlantic dispute over international relations is the same as that concerning domestic policies, only writ large. It's a conflict between two ideologies. One is based on the presumption that individuals and nations should be self-reliant and free to develop their own capacities (forming 'coalitions of the willing' if they want) without being overly coerced by national or global elites. The other is based on the presumption that no individual or nation can go off and do as it pleases them, but should work instead within governing institutions that establish norms and provide security. Accordingly, 'multilateralism' has different meanings on the two sides of the Atlantic. Most Europeans believe in what Robert Kagan called principled multilateralism. In their view, gaining international approval (e.g. of U.N. Security Council) is not a means to an end but an end in itself, the sine qua non for the legitimacy of an action on the international arena. Even if the United States were absolutely right about Iraq, Europeans believe the United States would be wrong to invade without formal approval of the international community. On the other hand, most Americans are not principled multilateralists. They are instrumental multilateralists. Their formula, descending from the Clinton's presidency, is "multilateralism if possible, unilateralism if necessary". Richard Haas, a high ranking Washington official, put the idea this way: "No organization, not even the United Nations, has a monopoly on legitimacy; rather, legitimacy depends most on the rationale for an action and the manner in which it is undertaken". ${ }^{22}$

This is deeply troubling for the Europeans. They have already transferred much of the authority of their nation states to supranational organizations of the European Union, and European life is ever more regulated by powers beyond national control, by a post-national regime of EU multilateralism. As Javier Solana insisted, the demand for multilateralism was not a ploy of Europeans to tie down the American giant by international agreements: "The European attachment to a multilateral approach in those issues is a matter of conviction, not of malign strategy. Our experience tells us that sovereignty shared is sovereignty magnified. To misquote Sir Winston Churchill, multilateralism is the worst of

${ }^{22}$ Haas, Richard, [State Department Policy Planning Staff, Director] 'Sovereignty: existing rights, evolving responsibilities', remarks to the School of Foreign Service and the Mortara Center of International Studies, Georgetown University, 14 January 2003. 
international government, except all the others have been tried." ${ }^{23}$ No wonder that Donald Rumsfeld's blunt assertion "the worst thing you can do is allow a coalition to determine what your mission is" caused an uproar in Europe. On the American view, international institutions "whatever legitimacy they possess will have to be based on the underlying legitimacy of nation-states and the contractual relationships they negotiate" ..."Europeans, by contrast, tend to believe that democratic legitimacy flows from the will of an international community much larger than any individual nation-state." ${ }^{24}$ Americans tend to be individualist, while Europeans lean towards collectivism. On the collectivist view of the world politics, only collectivities can have the right to define missions: missions are to be distilled from, and to have the approbation of, the collective will. While for a collectivist an action is illegitimate unless approved by a collective, for an individualist an action is legitimate unless proven otherwise.

Europe and America thus have different views of the source of agency in world politics. For the past few decades, Europeans have been engaged in the process of dismantling the nation-state and denationalizing political life, and this is why they now consider American displays of nationalism, or unilateralism, anachronistic. Many Americans, by contrast, consider the European endeavor with great suspicion, as a ploy for the realization of the social-democratic dream at the international and ultimately at the global level. They fear that the European model of governance would lead to "transnational progressivism" and to the rule of the 'Acronymia' of supranational organizations. ${ }^{25}$

"The choice between unilateralism and multilateralism", writes Russell Berman, "points far beyond the technicalities of international relations. A difference between two fundamentally distinct cultural worldviews is at stake. Multilateralism involves, by definition, an infringement of individual prerogative and implies the deferral of responsibility to a regime of committees, which - as the political theorist Hannah Arendt would have put it - is a responsibility of no one. ... It has a consequence in domestic policy as well as international relations: the overcoming of egoism. The association of the United States with unilateralism, in contrast, involves a different notion of liberty, outside the state and outside the suprastate." ${ }^{26}$ Francis Fukuyama concurs: "Whether in regard to welfare, crime, regulation, education or foreign policy, there are constant differences separating America from everyone else. It is consistently more anti-statist, individualistic, laissez-faire and egalitarian than other democracies. ${ }^{\prime 27}$ This

\footnotetext{
${ }^{23}$ Solana, Javier, 'Europe and America: partners of choice', speech to the annual dinner of the Foreign Policy Association, New York, 7 May 2003.

${ }^{24}$ Fukuyama, F., "The West May be Cracking: America vs. The Rest", New Perspectives Quarterly, vol. 21, no. 3, Summer 2004.

${ }^{25}$ Fonte, John, "Liberal Democracy vs. Transnational Progressivism: The Future of the Ideological Civil War Within the West",Orbis, Summer 2002; John O'Sullivan, "Gulliver's travails: The U.S. in the post-Cold-War world", The New Criterion, Vol. 23, No. 2, October 2004.

${ }^{26}$ Berman, Russell, Anti-Americanism in Europe: A Cultural Problem, Hoover Institution, 2004, 79-80.

${ }^{27}$ Fukuyama, F., op. cit.
} 
is the Anglo-Saxon notion that liberty rests with the individuals; it is not a privilege conferred by collectivities. The contrast is with the Continental (French) tradition, where the General Will is the source of any liberty conferred to individuals and their groups. The American political tradition has its origin in one particular predecessor in Europe, namely classical English liberalism. As a result, its political culture is much more monolithic than the European one. There is no American counterpart of the left-right divide in Germany or France. And the European type social democracy has never achieved, nor is likely to achieve the high ground of mainstream politics in America. ${ }^{28}$ As the authors of The Right Nation put it, "the center of gravity of American opinion is much further to the right - and the whole world needs to understand what that means." ${ }^{29}$

Both for the cultural elite and on the level of broad cultural values, the differences between Western Europe and the United States are significant, implying important political ramifications. Their different conceptions of freedom, their different visions of the good society lead to very different attitudes toward projecting their visions to the wider world. These differences better explain the current transatlantic acrimony than the imbalance of power which is probably a consequence rather than the cause of the rift within the West.

\section{Repercussions of the Rift: Old and New Europe}

It is hardly surprising that West European anti-Americanism had no real run in former captive nations of Central Europe and the Baltic States. The Central European states and the Baltic States, in particular, credit a strong and decisive America with bringing down the Soviet Union and helping them regain independence. The idea of national sovereignty is consequently strong here and it resonates well with American nationalism. However, the nationalism of Central and East European countries has been under considerable stress recently.

It seems that virtually all Central and Eastern European countries face a dilemma in the current transatlantic crisis. ${ }^{30}$ The two pillars of their post-communist policies have been integration into European and Transatlantic structures (primarily EU and NATO). They trust NATO as the main vehicle for effective defense, but only because membership in this organization implies close rela-

\footnotetext{
${ }^{28}$ Recently there has been a flow of studies purporting to draw the distinction between European and American (more precisely, Anglo-Saxon) political traditions: Alan MacFarlane, The Riddle of the Modern World: Of Liberty, Wealth and Equality, Palgrave Macmillan, 2002; Gertrude Himmelfarb, The Roads to Modernity: The British, French, and American Enlightenments, Knopf, 2004; Huntington, Samuel, Who Are We: The Challenges to America's National Identity, Simon and Schuster, 2004; James C. Bennett, The Anglosphere Challenge: Why the English-Speaking Nations Will Lead the Way in the Twenty-First Century, Rowman \& Littlefield Publishers, Inc., 2004.

${ }^{29}$ Micklewait and Wooldridge, op. cit., p. 11.

${ }^{30}$ See Budryte, D., „The Dilemma of 'Dual Loyalty': Lithuania and Transatlantic Tensions, in. Old Europe, New Europe and the US, ed. by Tom Lansford, Blagovest Tashev, Ashgate, 2005.
} 
tions with the USA, the most powerful member. And they want good relations with the USA because they do not believe that European 'core' nations, though also members of NATO, would have either the will or the power to come to their defense in case of need. Their skepticism is well founded. They have witnessed Europe's repeated failures to deal with the calamities in its own backyard, with the strong and decisive America repeatedly coming to the rescue. They were embarrassed when they saw France and Germany cooperate with Russia (and China) to block America's efforts at getting Security Council approval for the invasion of Iraq. They can also draw skeptical conclusions concerning European guarantees for their security from such facts that Germans have a much more favorable opinion of Vladimir Putin than of George W. Bush.

By lining-up behind the Americans on the issue of Iraq, Central and East Europeans (together with Britain, Denmark and the Netherlands) prevented Germany and France from creating an anti-American EU foreign policy. And they did not let themselves to be intimidated by threats from Paris and Berlin. The Washington Times announced that "the countries of Central and East Europe have become the major allies of America in Europe" ${ }^{31}$ The transatlantic rift thus made its appearance as a crack within Europe itself. On security issues Europe was obviously divided into pro- and anti-Americans, into 'new' and 'old' Europe-so much so that The Economist was led to wonder if NATO and the European Union were partners or rivals. ${ }^{32}$

However, on the other hand, the 'new' Europeans consider the EU the main vehicle for their economic development. This stance of being pro-American on security issues while being pro-EU on economic matters might prove to be unfeasible if the EU develops as a counterweight to the USA - which is exactly how the Franco-German tandem envisages its future. The 'new' Europeans thus seem to be faced with a dilemma: either effective defense (alliance with America) or economic growth (alliance with the Franco-German tandem in the EU), not both.

But is this a real dilemma? It is real only if it is granted that the EU as a political union is indispensable for the economic development of 'new' Europe. Precisely this can be doubted. It is far from obvious that the 'ever closer Europe', based as it is on the 'social model', would best serve the new-comers' economic interests. Indeed, one may wonder if a closer Europe is at all beneficial for them. The dilemma is premised on the idea that the European "social model" is a viable one and that even if less efficient it provides more "social security" than the "Anglo-Saxon" model. The premise, however, is increasingly coming under attack. British historian Paul Johnson claims that "the EU economic philosophy, in so far as it has one, is epitomized by one word "convergence". The aim is to make all national economies identical with the perfect model. This, as it turns out, is actually the perfect formula for stagnation. What makes the capitalist system work, what keeps economies dynamic, is precisely nonconformity, the new, the unusual, the eccentric, the egregious, and the innovative, springing

\footnotetext{
31 "A Ticket to the New Europe", Washington Times, 9 February 2003, p. 4.

32 "NATO and the European Union", The Economist, February 26, 2005.
} 
from the inexhaustible inventiveness of human nature." ${ }^{\prime \prime 3}$ Overregulation and conformity, coupled with monopoly powers of the trade unions, lead to stagnation and high unemployment in the 'core' Europe, giving the lie to the promise of security and solidarity. ${ }^{34}$ The situation is further exacerbated by the impending collapse of the social security system with Europe's populations growing older and with birth rates far below the reproduction level.

There is a growing concern, not least in Germany and France, that the 'social model' is deeply flawed and that reforms are needed to bring it closer to the 'Anglo-Saxon" one. In fact, the disease now suffered by the 'core' Europe is analogous to that the US and Great Britain themselves suffered in the 1970s. The British and to a lesser extent the Americans have already had "social models" implemented and found them deficient. As is generally recognized, it was the free market reforms initiated by Reagan and Thatcher that had put an end to the stagnation and decline. It's no wonder that since the early 1980s the United States and the U.K. have had twice the rate of economic growth of Germany, France and Italy; unemployment rates in the U.S. and U.K. are under 5 percent while in Germany and France they are in double digits.

Analogous doubts about the feasibility of the "social model" have been expressed by the Czech President Vaclav Klaus who echoes the Nobel laureate economist Friedrich Hayek in pointing out the dangers of bureaucratic centralization in a political entity consisting of many different nations. According to Klaus, "integration" conceived as open markets is good, since it encourages competition and makes interventionism much less viable, while "unification" is definitely bad for a viable economy. Moreover, it is dangerous, for it attempts to forge a political unity where there is no "demos" to be united. ${ }^{35}$ Mart Laar, a well known Estonian politician expressed a similar view in his response to President Chirac's notorious outburst: "it is time for Europe to change. It must become more dynamic, decisive, competitive, open and future-orientated. European nations can retain their unique identities, while remaining open to each other. This is the real European identity - not some false oneness." ${ }^{\prime 36}$ These critical voices are quite numerous. How is it possible to have the economic benefits of EU without the costs of the 'ever closer union'? David Hannan, a British conservative MP, suggests an answer. Britain, in his view, needs to retain trade links with the EU with close inter-governmental co-operation, but not with political assimilation. This is no utopia, for consider the members of the European Free Trade Area (EFTA): Norway, Switzerland, Iceland and Lichtenstein. "They participate fully in the four freedoms of the single market - free movement of goods, services, people and capital. But they are outside the Common Agricultural and Fisheries

\footnotetext{
${ }_{33}$ Johnson, P., "What Europe Really Needs", The Wall Street Journal, Friday, June 17, 2005.

${ }^{34}$ See Gersemann, O., op. cit., Ch. 2, 3.

35 "Ich habe Angst um Europa" [I am afraid for Europe], interview mit Vaclav Klaus, Frankfurter Allgemeine Zeitung, 15.03.2005.

${ }^{36}$ Laar, Mart, "New Europe Won't 'Keep Quiet' Until All Europe Is New”, The Wall Street Journal, February 19, 2003.

${ }^{37}$ Hannan, Daniel, „The EU can work for Britain - if we quit,“ The Daily Telegraph, 28/08/ 2005.
} 
Policies, they control their own borders and human rights questions, they are free to negotiate trade accords with non-EU countries and they pay only a token sum to the EU budget. Unsurprisingly, they are much richer than the EU members. According to the OECD, per capita GDP in the four Efta countries is double that in the EU."'37 Is this a prospect that would be welcome by the 'new' Europe?

With the failure of referenda on the EU constitution in France and Netherlands and with the subsequent British revolt on the EU budget it has become evident that Europe is as divided on matters of economy as on security. The EU Summit in Brussels of June 16 to 17, 2005 turned out as 'battle ground' of diverging views on the future direction of Europe, in political and economic terms. One may wonder whether the Central and East Europeans are willing and/or able to prevent Germany and France from creating an anti-American EU economic policy. Can their pro-Americanism on security translate into an anti-EU (French-German) stance on economic issues? Would they dare to side with the British against 'core' Europe? Can Europe's dominant parties from across the political spectrum - from the Right in Germany, Italy and the Netherlands to the Left in Sweden, Poland and Portugal - converge on Mr. Blair as the potential standard-bearer for a new vision of Europe which is less politically ambitious but more economically dynamic. There are no simple answers to these questions.

The 'new' Europeans might choose to play the opportunistic game of trying to please both parties of the divide and thus to gain some small pay-offs. It would be the usual interest groups politics often leading to zero-sum or negative-sum outcomes. This seems to be the dominant position, currently also in Lithuania's foreign policy. ${ }^{38}$ Lithuania's "long-term" economic policy is also based on a naïve hope: "Lithuania, being an EU old-timer by that time" and "having modernized its economic policies and receiving EU financial and technical support" would have implemented "the EU socio-economic model, namely that of a welfare state with low unemployment, high labor costs, strong social guarantees and a high level of social solidarity." ${ }^{\prime 39}$ Or they might take a principled reformist stance on EU, as Estonians seem to do. The choice depends on many factors, including the availability of political acumen and the state of public opinion. For Lithuania's population at large one should admit that "it is still too early to make predictions ... regarding the similarities of societal values with the ones prevalent in America and Europe, because Lithuanian society is still in the process of transition... On the one hand, the experience of transition reforms makes some groups of the population prone to take risks, making them similar to the Americans. On the other hand, a still very strong attachment to the paternalistic state as evidenced by popular surveys might actually be reinforced

\footnotetext{
${ }^{38}$ Kaučikas, Nerijus, "Prancūzai ieško sąjungininkų" [The French are looking for allies], Veidas, Nr. 30, 2005 liepos 28. But there are also those inclining towards the British position, see: "Lietuva ir naujoji Europa, kuriuo keliu žengsime?"[Lithuania and new Europe: which way we are heading?] , Veidas, Nr. 27, 2005 liepos 7.

${ }^{39}$ Lietuvos respublikos ūkio ministerija, Lietuvos mokslų akademija, Lietuvos ūkio (ekonomikos) plètros iki 2015 metu ilgalaike strategija [The Long-Term Strategy up to 2015 of Lithuania's Economic Development], Vilnius, AB Vilspa, 2003, p. 20.
} 
by socializing with societies from European countries with extensive welfare conditions." ${ }^{\prime \prime 0}$ Much the same is true of other EU new-comers.

Anyway, the no-votes in France and the Netherlands in June 2005 with regard to the EU constitution made the dream (or fear) of deeper political integration and of an ever closer European Union evanescent. The EU now appears to be adrift. For some countries this is a time-out from the danger that even those corners of Europe that have resisted excessive government manipulation of the economy would be dragged toward the statist norm by EU rules. This is also a time-out for thought in preparation for tough decisions. There is also some chances that Miss Merkel and Mr. Sarkozy, who are quite likely to take the top political positions in Germany and France respectively, might be more willing to move closer to the British or the "Anglo-Saxon" model. But they do not seem to have the stamina of Mrs. Thatcher and Mr. Reagan to do what they did. Besides, they are operating in a social environment hostile to "surrender to neoliberalism". Yet they may be able to buy a little more time for Europe until the people realize there is no constructive choice other than following the Anglo-Saxon model of lower taxes, less government spending and regulation. And with the economic models getting closer there would be more chances of healing the transatlantic rift.

\section{Concluding Remarks}

We have argued that the causes of the transatlantic rift are mainly ideological, having to do with the difference between the mostly individualist (American) and the mostly collectivist (European) visions of the national and the international community. The difference helps explain a number of controversies and divisions between the two sides of the Atlantic. Security concerns, perception of threats, the role of international organizations, nationalism and religiosity as well as the issues of economic policy find different interpretations on the two sides of the Atlantic because of the different ideologies underlying the rift in the West. Central and East Europeans have already done their share in preventing the core Europe developing an anti-American EU foreign policy. It seems that now they have the window of opportunity for pushing the core Europe towards the evolution in a more American-friendly way on issues of social and economic policy. Failing this they risk not only catching the malaise of premature 'euro-sclerosis' but also that of forfeiting their security concerns. The challenge they face is formidable, yet not beyond their capacities.

Vilnius, September 15, 2005.

\footnotetext{
${ }^{40}$ Vilpišauskas, R., “The Dilemmas of Transatlantic Relations after EU Enlargement and the Implications for Lithuania", Lithuanian Foreign Policy Review, 2003/1-2 (11-12) http:// www.lfpr.lt/latest.phtml, 15092005.
} 